INDEPENDENT JOURNAL OF MANAGEMENT \& PRODUCTION (IJM\&P) http://www.ijmp.jor.br

V. 9, n. 3, July - September 2018

ISSN: 2236-269X

DOI: 10.14807/ijmp.v9i3.732

\title{
APPLICATION OF SIX SIGMA USING DEFINE MEASURE ANALYZE IMPROVE CONTROL (DMAIC) METHODOLOGY IN GARMENT SECTOR
}

\author{
Abdur Rahman \\ Shahjalal University of Science and Technology, Bangladesh \\ E-mail: airdipu@gmail.com \\ Salaha Uddin Chowdhury Shaju \\ Shahjalal University of Science and Technology, Bangladesh \\ E-mail: sust007@gmail.com \\ Sharan Kumar Sarkar \\ Shahjalal University of Science and Technology, Bangladesh \\ E-mail: sharan.sarkar303@gmail.com
}

Submission: $12 / 09 / 2017$

Revision: 06/03/2018

Accept: 15/03/2018

\section{ABSTRACT}

The aim of this paper is to demonstrate the empirical application of Six Sigma and Define-Measure-Analyze-Improve-Control (DMAIC) methodology to reduce product defects within a garments manufacturing organization in Bangladesh which follows the DMAIC methodology to investigate defects, root causes and provide a solution to eliminate these defects. Design of experiments (DOE) and the analysis of variance (ANOVA) techniques were combined to statistically determine the correlation of the broken stitch and open seam with defects as well as to define their optimum values needed to eliminate the defects. The analysis from employing Six Sigma and DMAIC indicated that the broken stitch and open seam influenced the number of defective products. Thus, a reduction of about $35 \%$ in the garments defect was achieved after the implementation of DMAIC methodology, which helped the organization studied to reduce its defects and thus improve its Sigma level from 1.7 to 3.4.

Keywords: Six Sigma; DMAIC Methods; Defects Reduction;

Garments Sector; Bangladesh

[http://creativecommons.org/licenses/by/3.0/us/]

Licensed under a Creative Commons Attribution 3.0 United States License 
INDEPENDENT JOURNAL OF MANAGEMENT \& PRODUCTION (IJM\&P)

http://www.ijmp.jor.br

v. 9, n. 3, July - September 2018

ISSN: 2236-269X

DOI: 10.14807/ijmp.v9i3.732

\section{INTRODUCTION}

Six Sigma was proposed by Motorola, in the mid-1980s, as an approach to improve production, productivity and quality, as well as reducing operational costs (BHOTE; BHOTE, 1991). The Sigma's name originates from the Greek alphabet and in quality control terms, Sigma $(\sigma)$ has been traditionally used to measure the variation in a process or its output (OMACHONU; ROSS, 2004).

In the Six Sigma's terminology, the "Sigma level" is denoted as a company's performance (Pyzdek; Keller, 2010). Particularly, a Six Sigma level refers to 3.4 defects per million opportunities (DPMO) (STAMATIS, 2004), or in other words, to have a process which only produces 3.4 defects per every one million products produced.

Besides being a measure of variability and organization's quality performance, Brue and Howes (2005) mention that Six Sigma is also a management philosophy and strategy as well as a problem-solving and improvement methodology that can be applied to every type of process to eliminate the root cause of defects. Some authors argue that the main benefits that an organization can gain from applying Six Sigma are: cost reduction, cycle time improvements, defects elimination, an increase in customer satisfaction and a significant rise in profits (DALE; WIELE; IWAARDEN, 2007; BREYFOGLE III; CUPELLO; MEADOWS, 2001).

Markarian (2004) suggests that not only can the process improvement generated by Six Sigma be used in manufacturing operations, as it is the case for the project presented in this paper, but it can also be expanded to improve business sectors such as logistics, purchasing, legal and human resources. In addition, Kumar et al (KUMAR et al., 2008).

State that although Six Sigma is normally used in defects reduction (industrial applications), it can also be applied in business processes and to develop new business models. Banuelas et al (BANUELAS; ANTONY; BRACE, 2005). Claim that other benefits such as (i) an increase in process knowledge, (ii) participation of employees in Six Sigma projects and (iii) problem solving by using the concept of statistical thinking can also be gained from the application of Six Sigma. To illustrate this point, during the utilization of Six Sigma in this research project, several tools and techniques were employed. 
INDEPENDENT JOURNAL OF MANAGEMENT \& PRODUCTION (IJM\&P)

http://www.ijmp.jor.br

v. 9, n. 3, July - September 2018

ISSN: 2236-269X

DOI: 10.14807/ijmp.v9i3.732

Therefore, skills in the use of these tools were built up within the staff of the Thai organization studied. Consequently, people involved in the project enhanced their knowledge and skills. As a reason, not only does an organization itself gain benefits from implementing Six Sigma in terms of cost savings, productivity enhancement and process improvement, but individuals involved also increase their statistical knowledge and problem-solving skills by conducting a Six Sigma project.

One of the Six Sigma's distinctive approaches to process and quality improvement is DMAIC (GARZA-REYES et al., 2010). The DMAIC model refers to five interconnected stages (i.e. define, measure, analyze, improve and control) that systematically help organizations to solve problems and improve their processes. Dale et al (DALE; WIELE; IWAARDEN, 2007) briefly defines the DMAIC phases as follows:

Define - this stage within the DMAIC process involves defining the team's role; project scope and boundary; customer requirements and expectations and the goals of selected projects (GIJO; SCARIA; ANTONY, 2011).

Measure - this stage includes selecting the measurement factors to be improved and providing a structure to evaluate current performance as well as assessing, comparing and monitoring subsequent improvements and their capability.

Analyze - this stage centers in determining the root cause of problems (defects), understanding why defects have taken place as well as comparing and prioritizing opportunities for advance betterment (ADAMS; GUPTA; WILSON, 2003).

Improve - this step focuses on the use of experimentation and statistical techniques to generate possible improvements to reduce the amount of quality problems and/or defects.

Control - finally, this last stage within the DMAIC process ensures that the improvements are sustained and that ongoing performance is monitored. Process improvements are also documented and institutionalized.

DMAIC resembles the Deming's continuous learning and process improvement model PDCA (plan-do-check-act) (DEMING, 1993). Within the Six Sigma's approach, DMAIC assures the correct and effective execution of the project by providing a structured method for solving business problems (HAMMER; GODING, 2001). 
Pyzdek (2003) considers DMAIC as a learning model that although focused on "doing" (i.e. executing improvement activities), also emphasizes the collection and analysis of data, previously to the execution of any improvement initiative. This provides the DMAIC's users with a platform to take decisions and courses of action based on real and scientific facts rather than on experience and knowledge, as it is the case in many organizations, especially small and medium side enterprises (SMEs) (GARZA-REYES et al., 2010).

\section{SIX SIGMA AND DMAIC APPLICATION}

DMAIC is a data-driven quality strategy used to improve defect rate or processes. It is an integral part of a Six Sigma initiative, but in general can be implemented as a standalone quality improvement procedure or as part of other process improvement initiatives such as lean.

\begin{tabular}{|l|l|l|l|l|}
\hline $\begin{array}{l}\text { What is the } \\
\text { problem? }\end{array}$ & $\begin{array}{l}\text { What data is } \\
\text { available? }\end{array}$ & $\begin{array}{l}\text { What are the root } \\
\text { causes of the } \\
\text { problem? }\end{array}$ & $\begin{array}{l}\text { Do we have the } \\
\text { right solutions? }\end{array}$ & $\begin{array}{l}\text { What do we } \\
\text { recommend? }\end{array}$ \\
\hline $\begin{array}{l}\text { What is the } \\
\text { scope? }\end{array}$ & $\begin{array}{l}\text { Is the data } \\
\text { accurate? }\end{array}$ & $\begin{array}{l}\text { Have the root } \\
\text { causes been } \\
\text { verified? }\end{array}$ & $\begin{array}{l}\text { How will we verify } \\
\text { the solutions } \\
\text { work? }\end{array}$ & $\begin{array}{l}\text { Is there support for } \\
\text { our suggestion? }\end{array}$ \\
\hline $\begin{array}{l}\text { What key metric } \\
\text { is important? }\end{array}$ & $\begin{array}{l}\text { How should we } \\
\text { stratify the data? }\end{array}$ & $\begin{array}{l}\text { Where should we } \\
\text { focus our efforts? }\end{array}$ & $\begin{array}{l}\text { Have the solutions } \\
\text { been piloted? }\end{array}$ & $\begin{array}{l}\text { What is our plan to } \\
\text { implement? }\end{array}$ \\
\hline $\begin{array}{l}\text { Who are the } \\
\text { stakeholders? }\end{array}$ & $\begin{array}{l}\text { What graphs } \\
\text { should we make? }\end{array}$ & $\begin{array}{l}\text { What clues have } \\
\text { we uncovered? }\end{array}$ & $\begin{array}{l}\text { Have we reduced } \\
\text { variation? }\end{array}$ & $\begin{array}{l}\text { Are result } \\
\text { sustainable? }\end{array}$ \\
\hline
\end{tabular}

DMAIC procedure is apply to our project for better tools and techniques used in the driven line for reducing defect rate.

\subsection{Data}

Here we select the C-14 line for the pilot run. The project was started from 1st November 2016. And its duration was taken 90 days which ends at 31st January 2017. The project was TQM base. All parties' involvement to reduce the project defect rate less than $2 \%$ is our goal which will impact our quality and efficiency.

There were some tools and techniques use for the defect reduction project. Some six sigma tools help to reduce the defect by using proper SOP of these tools. 
The project mainly follows DMAIC process. In individual stages of DMAIC six sigma tools helps to clear the path of the defect reduction.

\subsection{Background of the study}

First the line defect rate is more than $60 \%$ whereas the project defect rate is $43 \%$ respectively. Because of all buyer wants to check AQL level 2.5, the target would be project defect rate reduces less than $2 \%$. If we want to pass our good garments for shipment within Buyer required AQL $1.5 \%$ or $2.5 \%$, we have to fix up on an average $2 \%$ defect rate in a line or factory. It was found from the statistical analysis.

\subsection{Assumption}

Our focusing point is operator as a first QI. Individual process checking is much easier rather than whole body checking. Also, here TLS (traffic light system) maintained properly. We also focused on preventive maintenance of the machine by maintaining various machine components life time. The project defect root-cause would be identified on time and involve all party's awareness. It will be helpful to reduce the defect rate.

\subsection{Scope}

The scope would be identified from the fishbone diagram. Here 6M's (Men, Machine, Material, Mother Nature, Method \& Measurement) involved to analyze the project. It will help to reach the root-cause direction. It will much easier to problem finding and solving.

\subsection{Milestone}

The desired goal is to achieve project defect rate less than $2 \%$. Also, the milestone is to complete the project within desired time so that all project related work is visualized by the Gantt chart accordingly.

\subsection{Impact statement}

If the Defect rate is decreasing day by day, the required output will increase much higher than the present situation or vice-versa. Also, it would be helped to improve the workers performance as well as line efficiency.

\subsection{Success Measurement}


INDEPENDENT JOURNAL OF MANAGEMENT \& PRODUCTION (IJM\&P)

http://www.ijmp.jor.br

v. 9, n. 3, July - September 2018

ISSN: 2236-269X

DOI: 10.14807/ijmp.v9i3.732

The reduction of project defect rate increasing success of this project. The measurement of defect rate would be calculated from the overall line defect through entry into the excel data sheet. This measurement sheet also helps to calculate the

DPMO of the project. It would be helpful to know the line sigma level. Also, ${ }_{p k}$ apply to know the process capability and sigma level of the project too.

\subsection{Implementation of Six Sigma}

Six Sigma can be a great success or failure, depending on how it is implemented. Implementation strategies can vary organization to organizations, depending on their distinct culture and strategic business goals. After completing a needs assessment and deciding to implement Six Sigma, an organization has two basic options: Implement a Six Sigma program or initiative and create a Six Sigma infrastructure.

\subsection{The Metrics of Six Sigma}

Much confusion exists relative to the metrics of Six Sigma. The sigma level (that is, sigma-quality level) sometimes used as a measurement within a Six Sigma program includes a $\pm 1.5 \mathrm{~s}$ value to account for typical shifts and drifts of the mean, where $s$ is the standard deviation of the process. This sigma-quality level relationship is not linear. In other words, a percentage unit improvement in parts per million (ppm) defect rate (or defect per million opportunities [DPMO] rate) does not equate to the same percentage improvement in the sigma-quality level. Three common measures of process performance are - Defects per Unit (DPU), Defects per Million Opportunities (DPMO) and Parts per Million Defective (PPM). The key to understanding the difference between these terms is to understand the difference between a defect and a defective item:

A defect refers to a flaw or discrepancy on an item where more than one flaw (defect) can be found. For example, a hospital admission form contains several fields of information that can be missing or incorrect, so a given form can have more than one defect. This means that a sample of 10 forms can show more than 10 defects.

An item is said to be defective when the decision is made that the item is not acceptable, based either on one characteristic or the accumulation of multiple defects. This means that a sample of 10 items can show a maximum 10 defective units. 
Defects per unit (DPU) - the average number of defects per unit of product.

$D P U=\frac{\text { total number of defects found in a sample }}{\text { sample size }}$

For example, when 26 defects (flaws) are found on 10 units of product, the DPU is $26 / 10$ or 2.6 defects per unit.

Defects per Million Opportunities (DPMO) - a ratio of the number of defects in 1 million opportunities when an item can contain more than one defect. To calculate DPMO, you need to know the total number of defect opportunities.

$$
\begin{aligned}
& \text { DPMO }=\left(\frac{\text { Total number of defects found in a sample }}{\text { Total number of defect opportunities in the sample }}\right) \times 1,000,000 \\
& =\left(\frac{\text { Total number of def ects found in a sample }}{\text { Sample sizeXNumber of defect per wnit in the sample }}\right) \times 1,000,00
\end{aligned}
$$

Parts per Million Defective (PPM) - the number of defective units in one million units. (PPM is typically used when the number of defective products produced is small so that a more accurate measure of the defective rate can be obtained than with the percent defective).

$$
P P M=\left(\frac{\text { Total number of defective whits found in a sample }}{\text { Sample size }}\right) \times 1,000,000
$$

\subsection{Process Capability $\left({ }_{p}\right)$}

Process Capability is one of best tools for determining six sigma by continuous improvement process. Process capability means that how the process is capable to do its job. To obtain the efficiency we have to measure the capability of the respective process which one has been performed by the machine or operator. Every process has been done its own capability by the machine or operator performance. It has a statistical formula based on USL (Upper specification limit) and LSL (Lower specification limit). If we want to determine the $C_{p k}$ value, then we should guess the ULS and LSL. They are not a fixed value it will vary from process to process and phenomenon to phenomenon. It depends on the respective person who will deal with in quality issue or production team. The formula is given below-

$C p=\frac{U S L-L S L}{6 \sigma}$

Where, ${ }^{\sigma}$ is the standard deviation. 


\subsection{Process Capability Index $\left(\mathrm{C}_{\mathrm{pk}}\right)$}

Process capability index is referred to $C_{p k}$. It means the expected process capability around the target value. Hence, we can say that $C_{p k}$ is nothing but the quality index. Here,

$U C P=\frac{U C L-\mu}{3 \sigma}$

And

$L C M=\frac{\mu-L S L}{3 \sigma}$

Where, ${ }^{\mu}$ and ${ }^{\sigma}$ are the mean and standard deviation. Now we can write the formula of $C_{p k}$ as,

$C_{p k}=\min (U C P$ or $L C P)$

It is known as the process capability index. If we want to reach in 6 sigma, then we have to more take care of every process and on its capability. It is one of the paramount statistical continuous improvement measuring tools by which we can know the three things together such as process capability, variability and sigma. Evrey businessmen or manufacturers desire $1.33 \mathrm{Cpk}$ and 6 sigma in the long run.

\section{METHODOLOGY}

In our defect reduction project, we use the DMAIC procedure to know the desired sigma level as well as our defect rate position. It also helps us for further improvement and what type of way we should follow the project. It is very important to know the level of project completion so that DMAIC procedure helps us to know the level of the project. Here every phase of the DMAIC has different tools which we apply for go to the sustainable phase for controlling the desired outcome of the project. Either it was defect rate or processes. The project have run on three months which also visualize by gantt chart.

The DMAIC process easily lends itself to the project approach to quality improvement encouraged and promoted by Juran (JURAN; GODFREY, 1992). The flowchart shows the DMAIC project how could go for right track and this chart help us for further decision what it is (BORROR, 2009). 
In this project DMAIC procedure followed for how quality of the garments can be increased. It helps the sort of the project daily where it is and how can go for further initiative. To meet the objectives of the project various quality tools and statistical anaysis has been done at the different stages. At first we have dealed with normal data sheet so that we we want to know the situaton of initial defect rate and along with the defects terms which defects are most occuring and find the root causes of that defects.

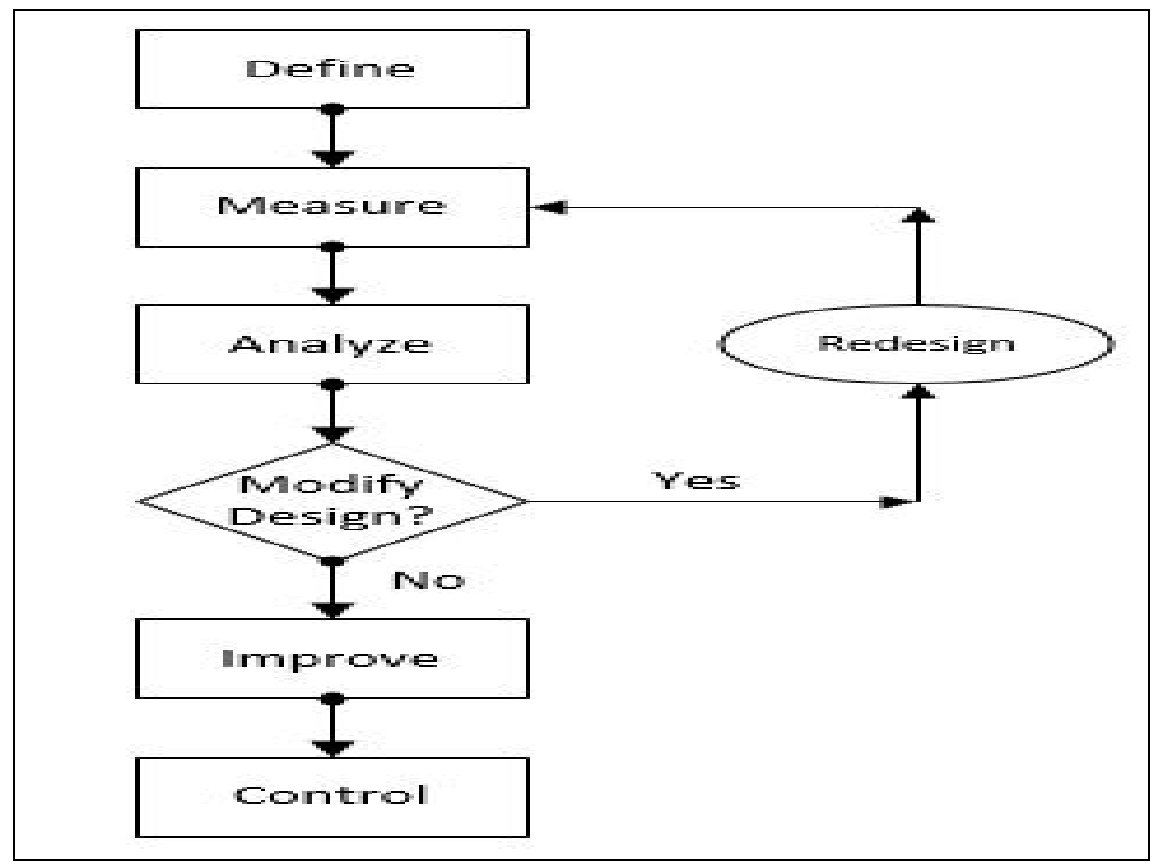

Figure 1: Flow chart of DMAIC project.

Besides ANOVA and regression analysis have been apllied to narrow the causes by using hypothesis and further action has been taken to resolve the defects from the production line to enhence the productivity and improve quality of the finished products. The regression model is given as,

$Y_{i}=\alpha+\beta X_{i}+e_{i}$

Where, $Y_{i}$ is the dependent variable, ${ }^{\alpha}$ and ${ }^{\beta}$ is the coefficients, ${ }^{e_{i}}$ is the error term.

\section{RESULTS AND DISCUSSION}

The voice of the customer (VOC) concept, which means identifying what the customers want and serving priorities to their needs, was used in this project to 
INDEPENDENT JOURNAL OF MANAGEMENT \& PRODUCTION (IJM\&P)

http://www.ijmp.jor.br

v. 9, n. 3, July - September 2018

ISSN: 2236-269X

DOI: 10.14807/ijmp.v9i3.732

define, based on customer requirements we have select project's objective. From this point, voice of customer also ensured that the project problem, which was defects reduction, became first priority for the improvement team and organization.

A project summary, which is a tool used to document the targets of the project and other parameters at the outset which was employed to state and present the project's information structure as well as the summary of the project, VOC, goal and the team's role in this research project. The summary of the project is presented in Table 1.

Table 1: Summary of the project.

\begin{tabular}{|l|l|}
\hline Project Title: & Defects reduction in garment products \\
\hline $\begin{array}{l}\text { Background and reasons for selecting the } \\
\text { project: }\end{array}$ & $\begin{array}{l}\text { Huge number of garment products has been } \\
\text { rejected by customers due to defective. This } \\
\text { problem causes several types of losses to the } \\
\text { company i.e. time, materials, capital as well as it } \\
\text { creates customer's dissatisfaction, which } \\
\text { negatively affects the organization's image. }\end{array}$ \\
\hline Project Goal: & $\begin{array}{l}\text { To reduce the defects by 35\% after applying Six } \\
\text { Sigma into the garments manufacturing process. }\end{array}$ \\
\hline Voice of the Customer (VOC): & \begin{tabular}{l} 
Product's quality. \\
\hline Team members:
\end{tabular} \\
\hline Expected Financial Benefits: & $\begin{array}{l}\text { Production manager, an experience shop-floor } \\
\text { operator and the improvement project leader. } \\
\text { A considerable cost saving due to the defects } \\
\text { reduction. }\end{array}$ \\
\hline Expected Customer Benefits: & Receiving the product with the expected quality. \\
\hline
\end{tabular}

Table2: Manufacturing process - Current and Expected States.

\begin{tabular}{|l|c|c|c|c|}
\hline \multirow{2}{*}{ Major Types of Defects } & \multicolumn{2}{|c|}{ Number of Major Defects } & \multicolumn{2}{|c|}{ Sigma Levels } \\
\cline { 2 - 5 } & $\mathrm{C}^{*}$ & $\mathrm{E}^{*}$ & $\mathrm{C}^{*}$ & $\mathrm{E}^{*}$ \\
\hline Broken & 412 & 174 & 1.7 & 3.4 \\
\hline
\end{tabular}

$\mathrm{C}^{\star}=$ Current process performance $\mathrm{E}^{\star}=$ Expected process performance after the completion of the sixsigma project

Pareto analysis was carried out to identify the utmost occurring defects and priorities the most critical problem which was required to be tackled. The collected data was generated in the form of a Pareto chart, which is illustrated in Figure 2. The Pareto chart shown in Figure 2 indicated that the highest rate of defects was caused by broken stitch which contributed to over 48.52 percent of the overall number of defects.

Therefore, the improvement team and organization decided to initially focus on the reduction of the broken stitch defect. The broken stitch defect rate was then translated into the Sigma levels as 1.7 Sigma. The calculation of the Sigma metrics allowed the improvement team and organization to have a more detail and operational definition of the current state of the garments manufacturing process as 
INDEPENDENT JOURNAL OF MANAGEMENT \& PRODUCTION (IJM\&P)

http://www.ijmp.jor.br

v. 9, n. 3, July - September 2018

ISSN: 2236-269X

DOI: 10.14807/ijmp.v9i3.732

well as the Six Sigma's goal in terms of the garments process improvement. These are shown in Table 3.

The next stage in the Six Sigma project and following the DMAIC methodology, consisted in analyzing the root causes of this problem as well as identifying an appropriate solution.

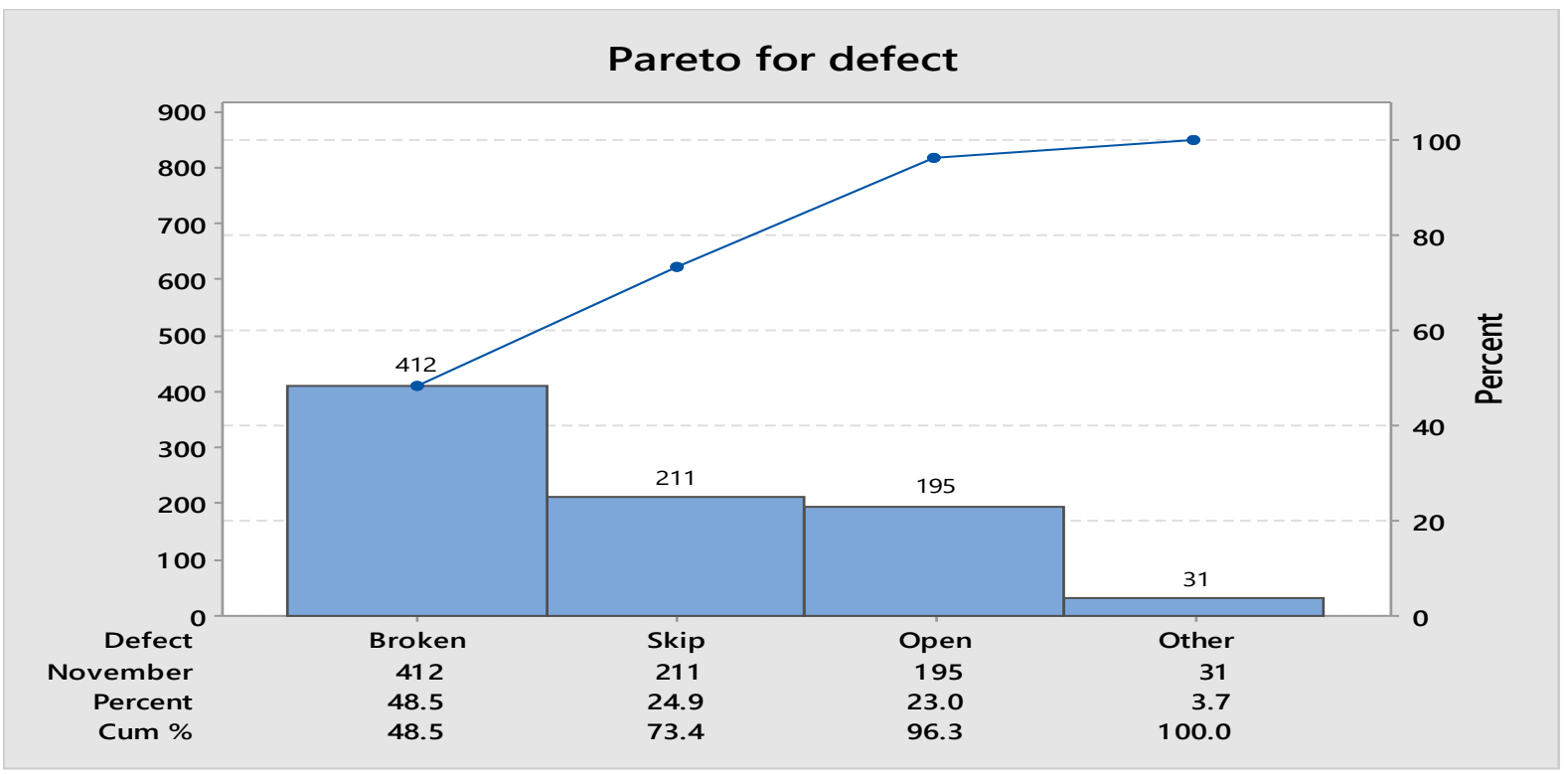

Figure 2: Pareto chart for defect.

The figure 3 shows that initial line Defect Rate(DR) was too high that is 64 to 62 parcent and which was gradually decreasing day after day within one month. Finally it shows the 24 parcent defect rate at the end of one month.

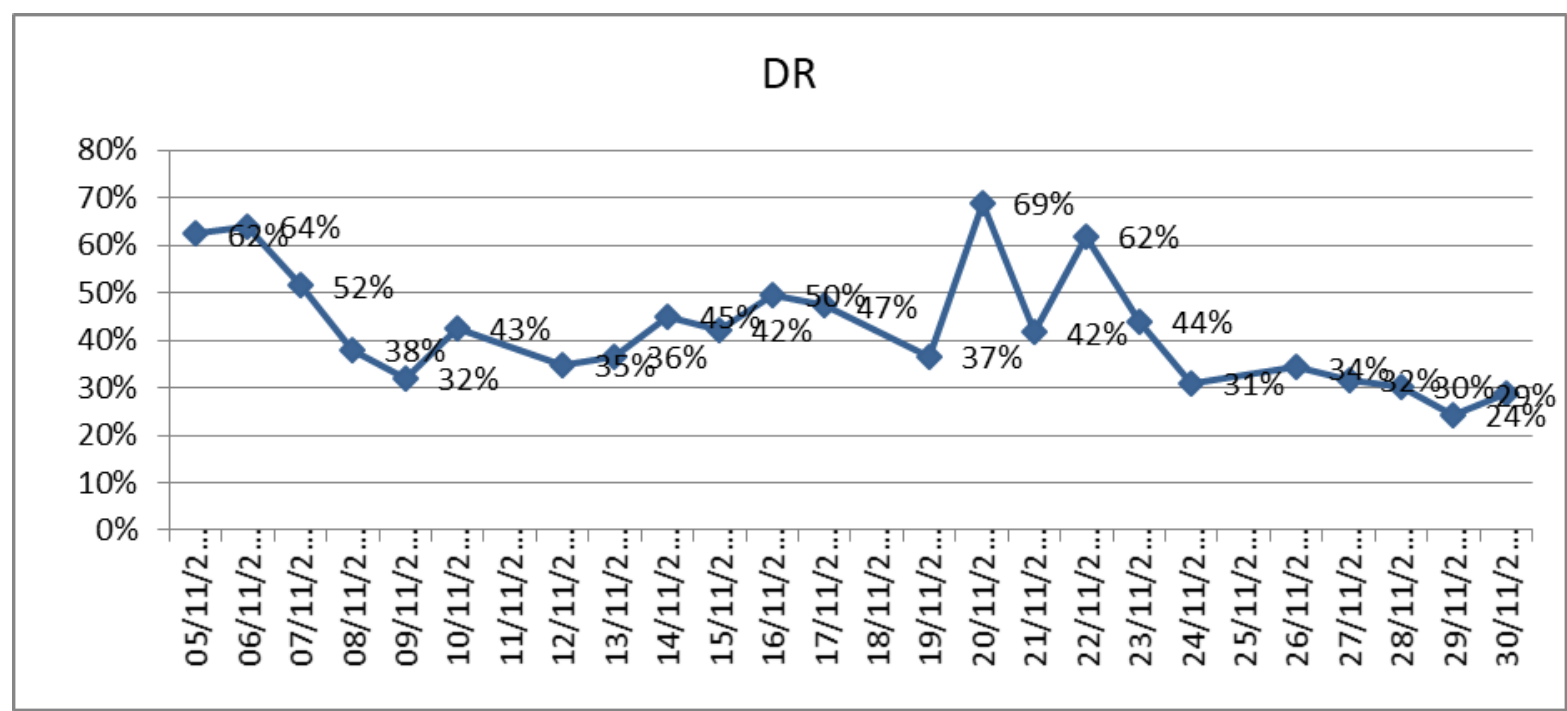

Figure 3: Project line defect rate (DR) before implimentation. 
INDEPENDENT JOURNAL OF MANAGEMENT \& PRODUCTION (IJM\&P)

http://www.ijmp.jor.br

v. 9, n. 3, July - September 2018

ISSN: 2236-269X

DOI: 10.14807/ijmp.v9i3.732

The figure 4 shows that initial project Defect Rate (DR) was too high that is 43 to 39 parcent and which was gradually decreasing day after day within one month. Finally it shows the 7 parcent defect rate at the end of one month.

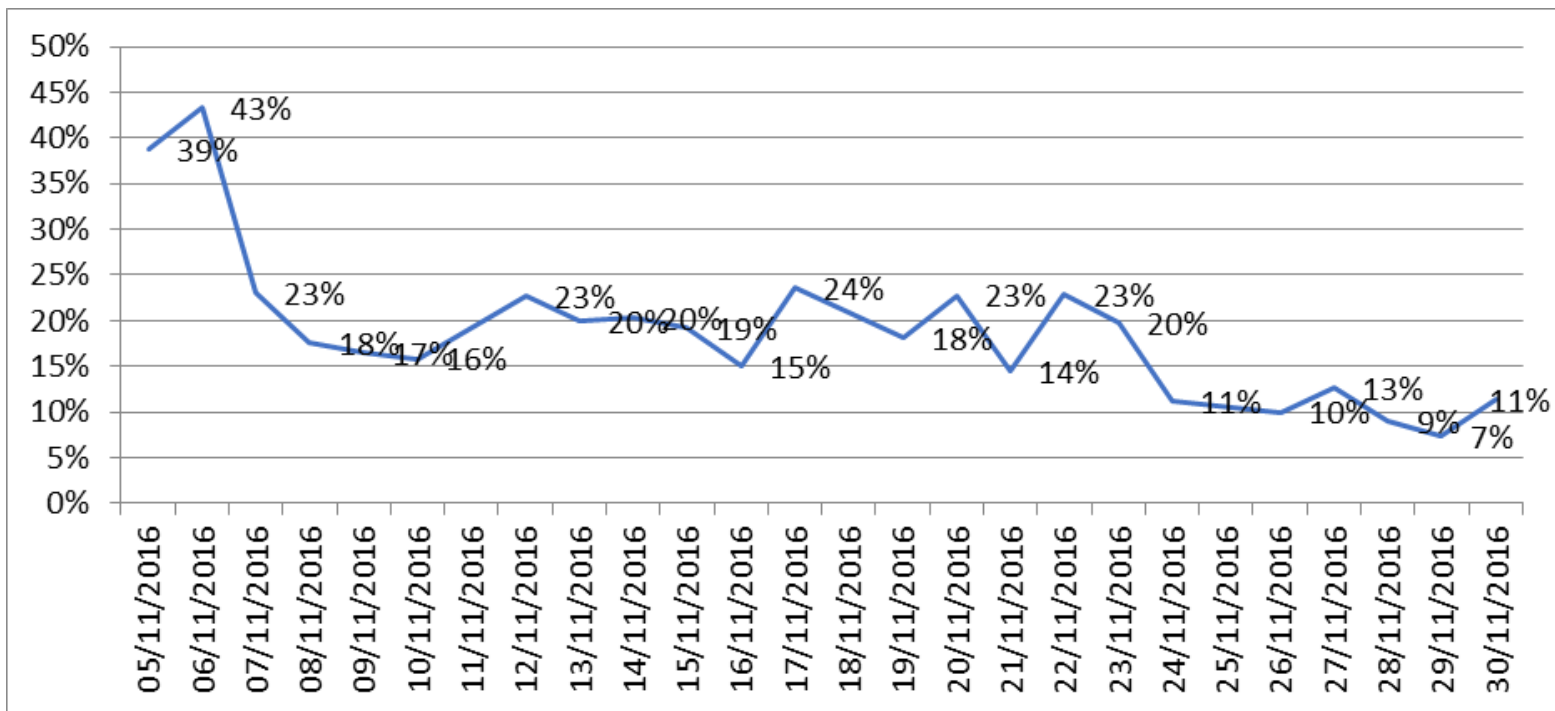

Figure 4: Project defect rate (DR) before implimentation.

The figure 6 shows that initial line Defect Rate(DR) was too high that is 47 to 43 parcent and which was gradually decreasing day after day within the dead line. Finally it shows the 14 parcent defect rate at the end of the project dead line.

\section{Cause \& Effect Diagram}

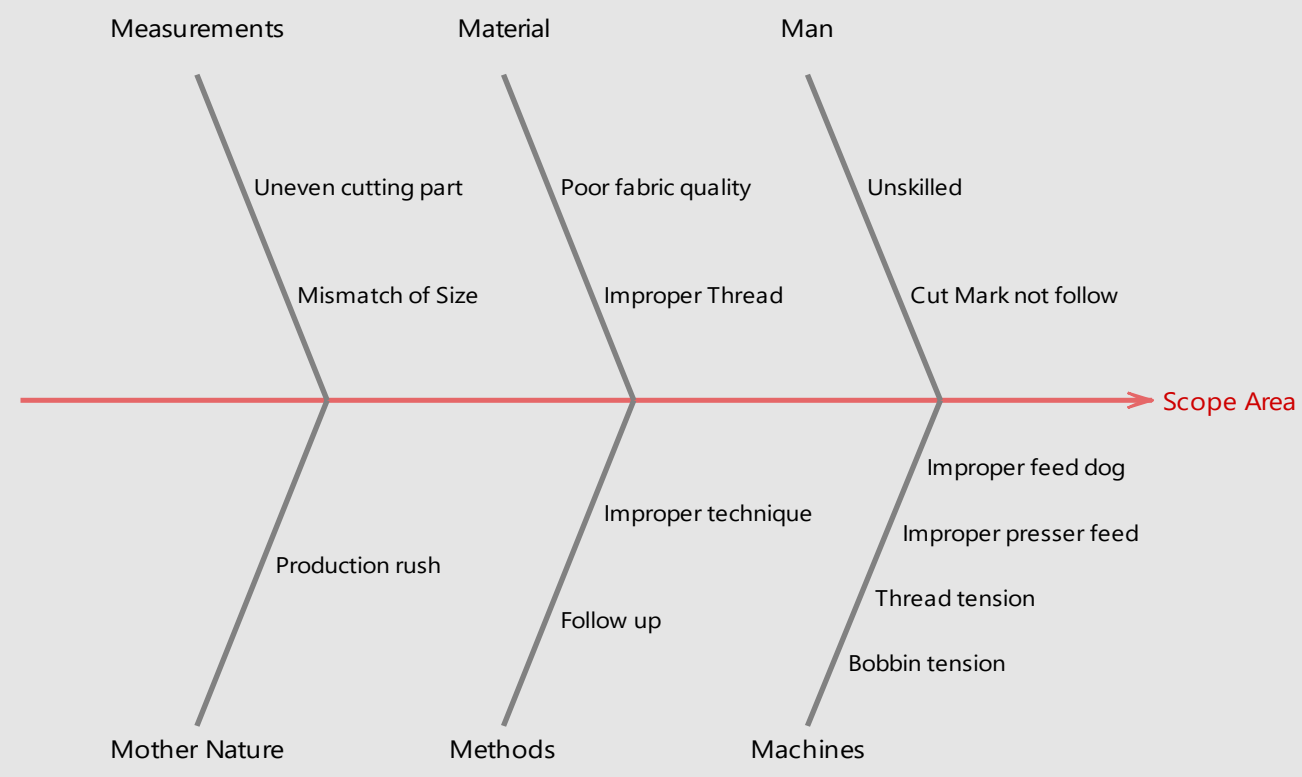

Figure 5: Cause and effect diagram for scope area. 
INDEPENDENT JOURNAL OF MANAGEMENT \& PRODUCTION (IJM\&P)

http://www.ijmp.jor.br

v. 9, n. 3, July - September 2018

ISSN: 2236-269X

DOI: 10.14807/ijmp.v9i3.732

The figure 7 shows that initial project Defect Rate(DR) was too high that is 17 to 14 parcent and which was gradually decreasing day after day within the dead line. Finally it shows the 2 parcent defect rate at the end of the project dead line.

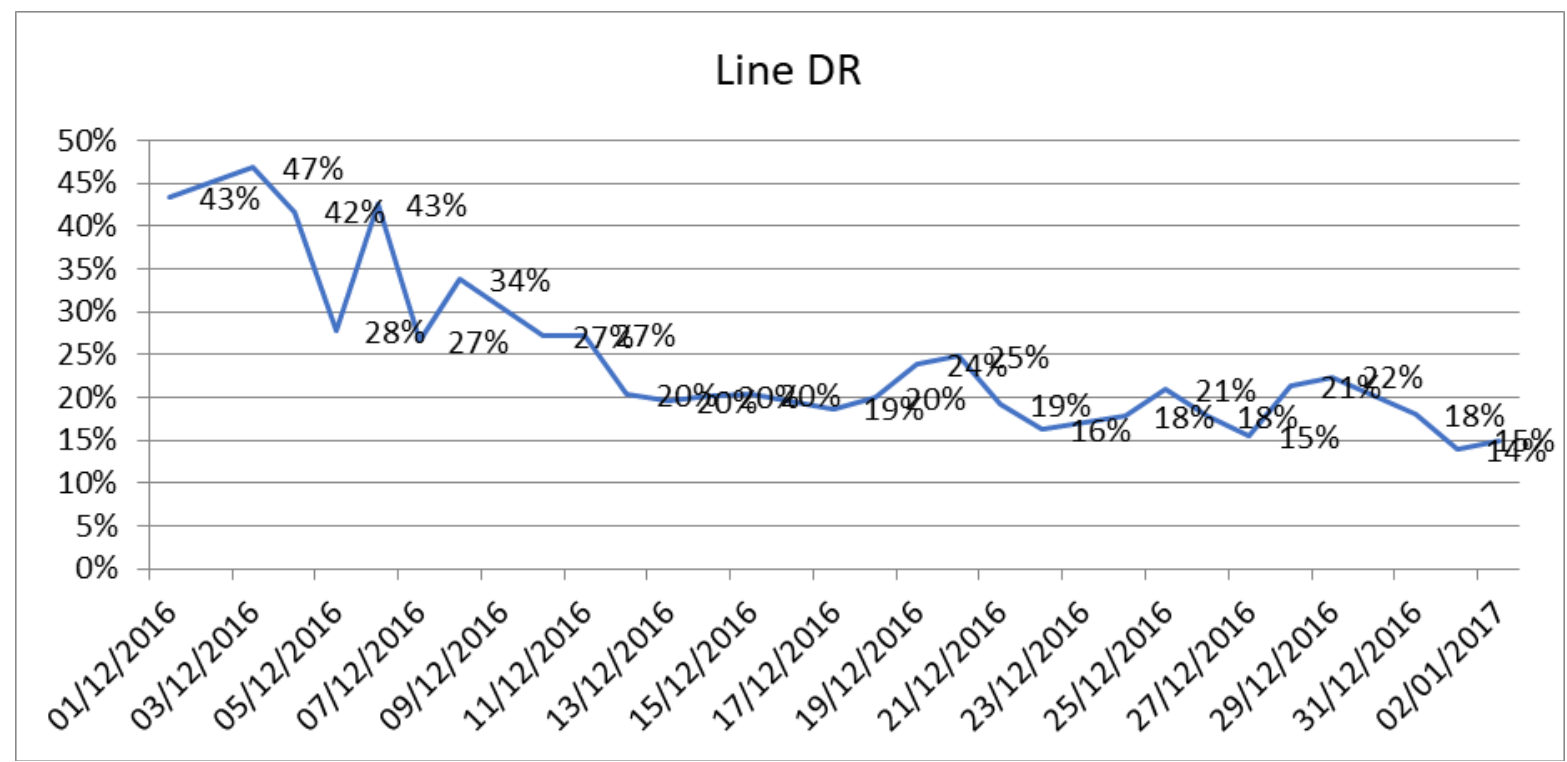

Figure 6: Line defect rate (DR) after impimentation DMAIC.

The figure 8 shows that the initial Sigma level of the project was defined 1.7 and also shows that it is increasing day bay day after implimenting necessary steps for defect reduction project. At the end of the project is being seen that we have achived the 3.4 Sigma which one is good but not best.

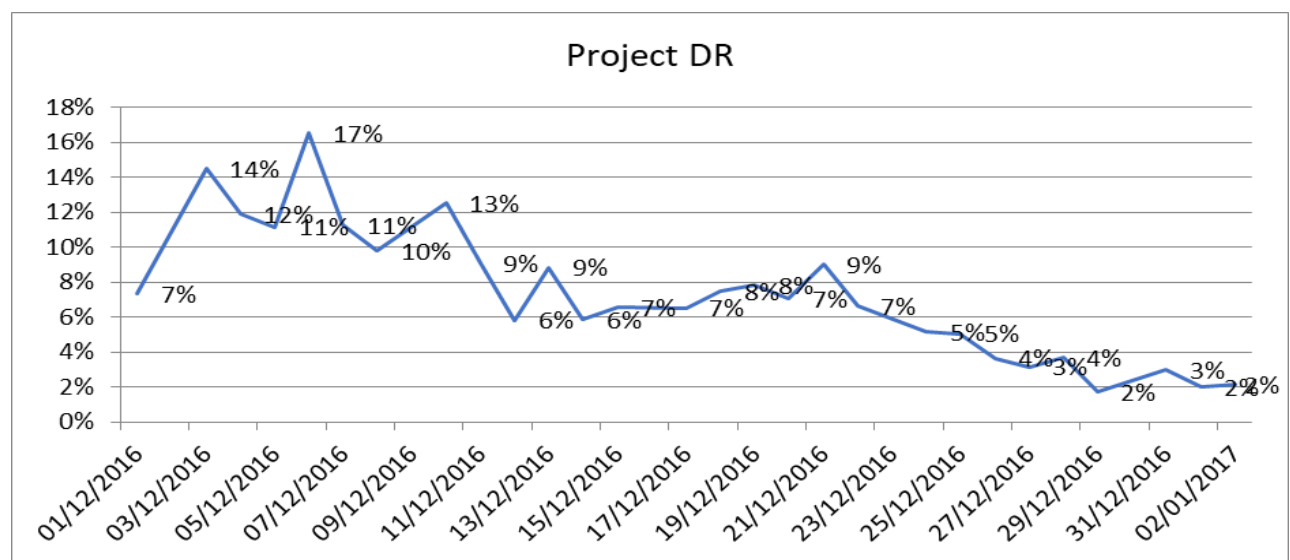

Figure 7: Project defect rate(DR) after impimentation DMAIC. 


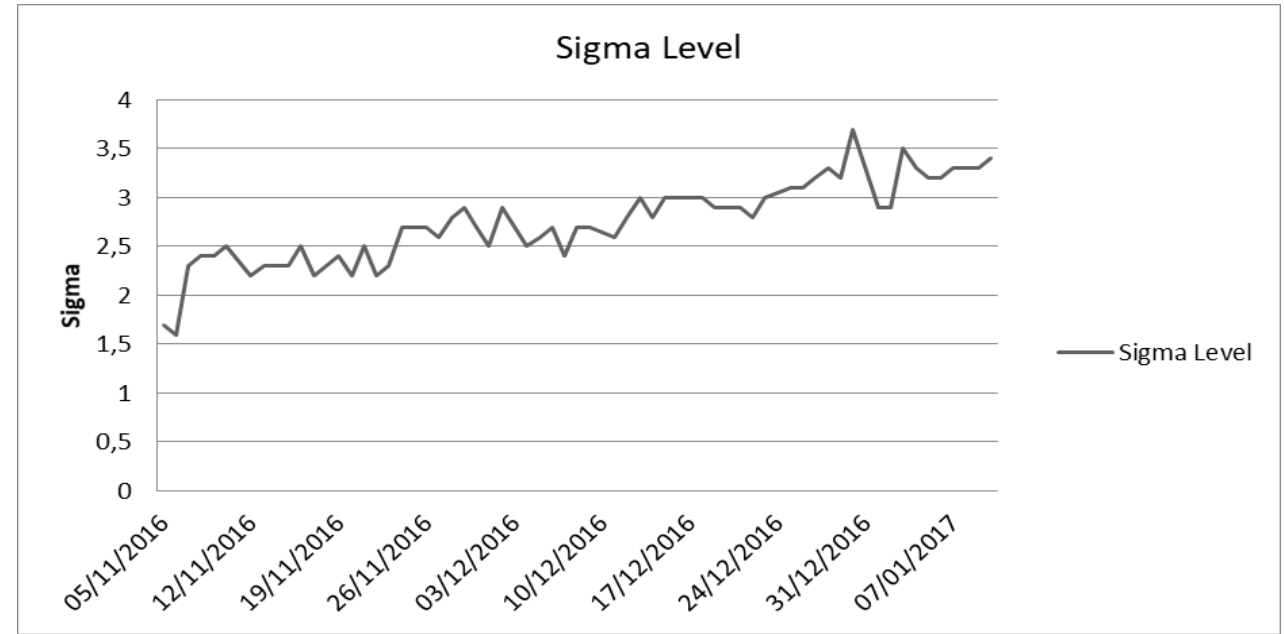

Figure 8: Project Sigma level.

The figure 8 shows that the another tool for reduction the process variablity and to improve the quality based product which is process capability(Cpk) and Sigma. It tells that the Cpk value is about 0.88 too low that means process variabilty is so high besides $\mathrm{Z}$ (sigma) is also about 2.88 too low. Evrey businessmen or manufacturers desire $1.33 \mathrm{Cpk}$.

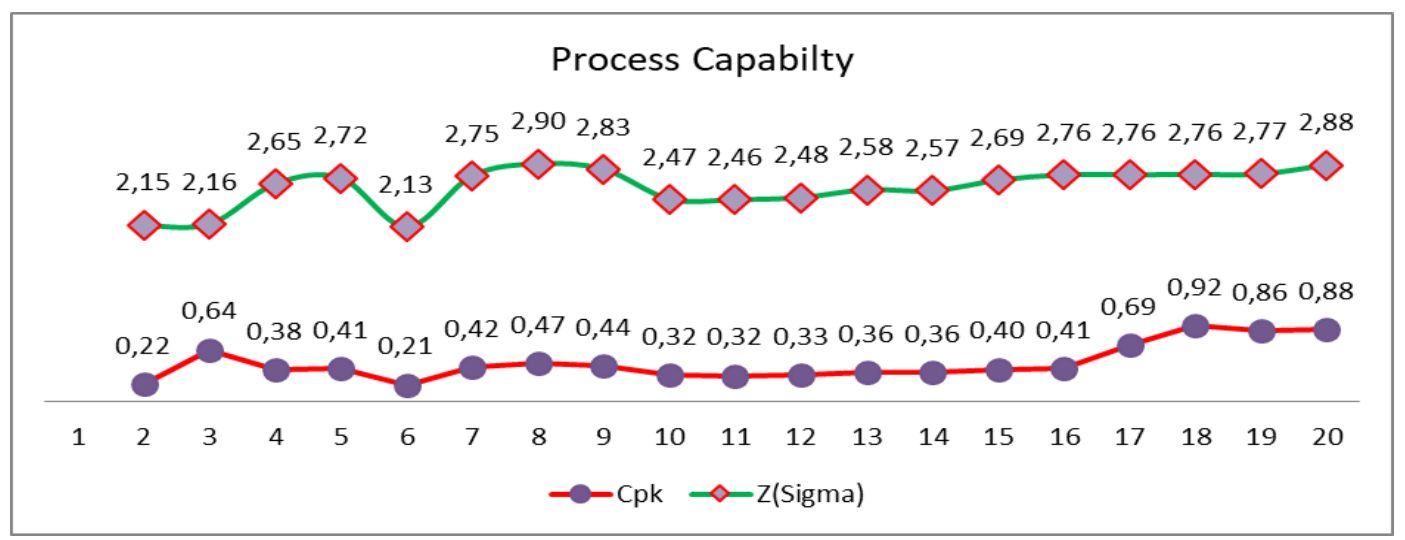

Figure 9: Process Capability(Cpk)\& Z(Sigma).

Analysis of variance (Table 3) tells that the overall variation is accounted by the average response variables. Above analysis shows that the assume hypothesis is statistically significant to be P-value $<0.05$. So, there is a significant effect among the full process. Another hypothesis tells the mean difference among the individual treatment mean.

Table 3: Analysis of Variance (ANOVA).

\begin{tabular}{|l|l|l|l|l|l|}
\hline Source & DF & Adj SS & Adj MS & F-Value & P-Value \\
\hline Defect & 4 & 93.53 & 23.383 & 7.60 & $0.000^{*}$ \\
\hline Parts & 2 & 2.24 & 1.119 & 0.36 & 0.695 \\
\hline Process & 20 & 76.62 & 3.831 & 1.25 & 0.213 \\
\hline Error & 399 & 1227.04 & 3.075 & & \\
\hline Lack-of-Fit & 75 & 185.82 & 2.478 & 0.77 & 0.913 \\
\hline
\end{tabular}


INDEPENDENT JOURNAL OF MANAGEMENT \& PRODUCTION (IJM\&P)

http://www.ijmp.jor.br

v. 9, n. 3, July - September 2018

ISSN: 2236-269X

DOI: 10.14807/ijmp.v9i3.732

\begin{tabular}{|l|l|l|l|l|l|}
\hline Pure Error & 324 & 1041.21 & 3.214 & & \\
\hline Total & 425 & 1489.03 & & & \\
\hline \multicolumn{5}{|c|}{ *5\% level of Significance } \\
\hline
\end{tabular}

Some treatments have a statistically significant mean difference effect that means they are highly correlated to occur defect. From the Table 4, they are Broken stitch, Open seam, Arm hole and Side pocket. The fitted regression model is,

Response $=2.246-0.658 *$ Broken Stitch-0.531*Open Seam+0.750*Arm Hole+0.632*Side Pocket

Table 4: Fitting the regression model.

\begin{tabular}{|l|l|l|l|l|l|l|}
\hline Term & Coefficient & SE Coefficient & T-Value & P-Value & VIF \\
\hline Constant & Broken Stitch & 2.246 & 0.196 & 11.45 & $0.000^{* *}$ & \\
\hline \multirow{4}{*}{ Defect } & -0.658 & 0.177 & -3.71 & $0.000^{* *}$ & 2.21 \\
\cline { 2 - 7 } & Open Seam & -0.531 & 0.240 & -2.21 & 0.027 & 2.89 \\
\cline { 2 - 7 } & Puckering & 0.223 & 0.487 & 0.46 & 0.648 & 5.89 \\
\cline { 2 - 7 } & Skip Stitch & -0.020 & 0.210 & -0.09 & 0.926 & 2.65 \\
\hline Parts & Inside & -0.148 & 0.173 & -0.85 & 0.394 & 2.48 \\
\cline { 2 - 7 } & Shell Part & 0.091 & 0.177 & 0.52 & 0.607 & 3.26 \\
\hline \multirow{5}{*}{ Process } & Arm Hole & 0.750 & 0.277 & 2.71 & $0.007^{* *}$ & 2.29 \\
\cline { 2 - 7 } & Back Side & -2.32 & 1.69 & -1.38 & 0.170 & 30.09 \\
\cline { 2 - 7 } & Collar & -0.308 & 0.360 & -0.85 & 0.393 & 2.66 \\
\cline { 2 - 7 } & Cuff & 0.170 & 0.427 & 0.40 & 0.690 & 3.24 \\
\cline { 2 - 7 } & Eyelet/Button & -0.071 & 0.992 & -0.07 & 0.943 & 11.12 \\
\cline { 2 - 7 } & Front Side & 1.68 & 1.20 & 1.39 & 0.164 & 15.81 \\
\cline { 2 - 7 } & Hem & 0.188 & 0.467 & 0.40 & 0.688 & 3.50 \\
\cline { 2 - 7 } & Hood & -0.035 & 0.340 & -0.10 & 0.918 & 2.66 \\
\cline { 2 - 7 } & Label Main/Care & -0.50 & 1.20 & -0.42 & 0.675 & 15.78 \\
\cline { 2 - 7 } & Side pocket & 0.632 & 0.362 & 1.75 & $0.041^{* *}$ & 3.02 \\
\cline { 2 - 8 } & Loop & 0.610 & 0.726 & 0.84 & 0.402 & 6.55 \\
\cline { 2 - 7 } & Neck JNT/TS & -0.485 & 0.584 & -0.83 & 0.407 & 4.61 \\
\cline { 2 - 7 } & Placket & 0.407 & 0.314 & 1.30 & 0.196 & 2.70 \\
\cline { 2 - 8 } & Pocket & -0.472 & 0.333 & -1.42 & 0.157 & 2.74 \\
\cline { 2 - 7 } & Side Seam & -0.291 & 0.533 & -0.55 & 0.585 & 4.03 \\
\hline
\end{tabular}

**5\% level of Significance

\section{CONCLUSION}

The primary goal of this project is to identify action initiatives that make up the help of conducting the project in the next step in order to reduce the defect rate at $2 \%$ which is the main objective of the project and to increase the productivity and quality goods.

To that end, The Defect Reduction Project report shows that if it has been taken proper steps, then many defects are reduced by only applying some scientific method and also shows that process capability (Cpk) is an effective tool to reduce the variability and to increase the productivity and ensure the more quality product. 
INDEPENDENT JOURNAL OF MANAGEMENT \& PRODUCTION (IJM\&P)

http://www.ijmp.jor.br

v. 9, n. 3, July - September 2018

ISSN: 2236-269X

DOI: 10.14807/ijmp.v9i3.732

At the end, our project dead line we have been able to achieve the desired $2 \%$ defect rate. Finally, we can say that all types off assignable causes are able to control by reducing defect and continuous improvement process.

\section{ACKNOWLEDGMENT:}

We want to give thanks to the Managing Director of Snowtex Outerwear Ltd. S M Khalid Hasan for giving the opportunity and inspiration to run the project.

Conflict of Interest: We declare that there is no conflict of interest.

\section{REFERENCES}

ADAMS, C. W.; GUPTA, P.; WILSON JR., C. E. (2003) Six Sigma deployment, Elsevier Science, Burlington USA.

BANUELAS, R.; ANTONY, J.; BRACE, M. (2005) An application of Six Sigma to reduce waste, Quality and Reliability Engineering International, v. 21, n. 6, p. 553-570.

BHOTE, K. R.; BHOTE, A. K. (1991) World-class quality: using design of experiments to make it happen, 2nd Edition, American Management Association, New York.

BORROR, C. M. (2009) The certified quality engineer handbook, ASQ Quality Press, $2^{\text {nd }}$ ed., p. 321-332.

BREYFOGLE III, F. W.; CUPELLO, J. M.; MEADOWS, B. (2001) Managing Six Sigma, John Wiley \& Sons Inc., New York.

BRUE, G.; HOWES, R. (2005) Six Sigma: the MacGraw-Hill 36 hours' course, MacGraw-Hill, New York.

DALE, B. G.; WIELE, T.; IWAARDEN, J. (2007) Managing Quality, 5th Edition, Blackwell Publishing Ltd., Oxford.

DEMING, W. E. (1993) The new economic for industry, government, education, MIT Center for Advanced Engineering Studies, Cambridge, MA.

GARZA-REYES, J. A.; et al. (2010) An empirical application of Six Sigma and DMAIC methodology for business process improvement, Proceedings of the 20th International Conference on Flexible Automation and Intelligent Manufacturing (FAIM), July 12-14, California, US, 92-100.

GIJO, E. V.; SCARIA, J.; ANTONY, J. (2011) Application of Six Sigma methodology to reduce defects of a grinding process, Quality and Reliability Engineering International, (Online), 3 May 2011.

HAMMER, M.; GODING, J. (2001) Putting Six Sigma in perspective, Quality, v. 40, n. 10, p. 58-63.

JURAN, J.; GODFREY, A. B. (1992) Quality Handbook, The McGraw-Hill Companies, Inc. 
KUMAR, U. D.; et al (2008) On the optimal selection of process alternatives in a Six Sigma implementation, International Journal of Production Economics, v. 111, n. 2, p. 456-467.

MARKARIAN, J. (2004) Six Sigma: quality processing through statistical analysis, Plastics, Additives and Compounding, v. 9, n. 4, p. 28-31.

OMACHONU, V. K.; ROSS, J. E. (2004) Principles of total quality, 3rd Edition, CRC Press LLC, Florida.

PYZDEK, T. (2003) The Six Sigma handbook: a complete guide for green belts, black belts, and managers at all levels, McGraw-Hill Companies Inc., New York, NY. PYZDEK, T.; KELLER, P. A. (2010) The Six Sigma handbook: a complete guide for greenbelts, black belts, and managers at all levels, 3rd Edition, McGraw-Hill Companies Inc., New York.

STAMATIS, D. H. (2004) Six Sigma fundamentals: a complete guide to the system, methods and tools, Productivity Press, New York. 